\title{
Myometrial expression of 11 1 -hydroxysteroid dehydrogenase type 2 in rat pregnancy
}

\author{
P J Burton and B J Waddell \\ School of Anatomy and Human Biology, The University of Western Australia, Perth, WA, Australia \\ (Requests for offprints should be addressed to B J Waddell, School of Anatomy and Human Biology, The University of Western Australia, 35 Stirling Highway, \\ Nedlands, WA 6009, Australia; Email: bwaddell@anhb.uwa.edu.au) \\ (P J Burton is now at Concept Fertility Centre, King Edward Memorial Hospital, 374 Bagot Road, Subiaco, WA 6008, Australia)
}

\begin{abstract}
The enzyme 11ß-hydroxysteroid dehydrogenase type 2 $(11 \beta-H S D 2)$, which reduces glucocorticoid potency in target cells by metabolism of active glucocorticoids, is expressed in the non-pregnant rat uterus in an oestrogendependent manner. Because glucocorticoids appear to facilitate parturition in many species, expression of $11 \beta-$ HSD2 in pregnant myometrium is likely to influence pregnancy maintenance and possibly the onset and progression of labour.

The present study therefore examined myometrial $11 \beta-H S D 2$ mRNA, protein and bioactivity across rat pregnancy, with emphasis on the peripartum period. A single $1.9 \mathrm{~kb}$ transcript of $11 \beta$-HSD2 mRNA was evident in myometrium at all stages, with maximal $(P<0 \cdot 05)$ levels observed at day 16 (term $=$ day 23). Consistent with this pattern of mRNA expression, Western blot analysis showed the presence of a $40 \mathrm{kDa} 11 \beta-\mathrm{HSD} 2$ protein at all stages, with the maximal immunoreactive signal also observed on day 16 . The $11 \beta-H S D 2$ signal was immunolocalized to myometrial smooth muscle cells and endometrial stromal cells. Bioactivity specific to $11 \beta-\mathrm{HSD} 2$
\end{abstract}

was detectable in myometrium at all stages, but in contrast to the patterns of $11 \beta-H S D 2$ mRNA and protein, the $\mathrm{V}_{\max }$ decreased at the beginning of pregnancy and remained stable until term. The apparent $K_{\mathrm{m}}$ of $11 \beta-H S D 2$ for corticosterone increased from $47 \pm 11 \mathrm{nM}$ in non-pregnant myometrium to $75 \pm 7 \mathrm{nM}$ by day 10 of pregnancy, and remained high until returning to an intermediate level on the day of delivery $(60 \pm 8 \mathrm{nM})$. Progesterone competitively inhibited 11ß-HSD2 bioactivity $\left(K_{i}=1.75 \mu \mathrm{M}\right) \quad$ whereas $20 \alpha$-hydroxypregn-4en-3-one, the other major progestin present during rat pregnancy, had no such effect.

In conclusion, these data suggest that local levels of active glucocorticoid in the myometrium are determined by the net effects of myometrial $11 \beta-H S D-1$ and -2 expression across pregnancy. Because the previously reported increase in myometrial $11 \beta-H S D-1$ near term occurs with little change in myometrial $11 \beta-H S D 2$ bioactivity, this is likely to facilitate parturition by increasing local concentrations of active glucocorticoid.

Journal of Endocrinology (2002) 172, 519-526

\section{Introduction}

The uterine myometrium is a highly dynamic and adaptable tissue crucial to pregnancy maintenance and parturition, and its growth and function are influenced by a range of hormones including the female sex steroids and glucocorticoids (Challis et al. 2000, Whittle et al. 2001). Important effects of glucocorticoids on myometrial function include the inhibition of prostacyclin synthesis (Casey et al. 1985) and the upregulation of oestrogen receptor mRNA (Wu et al. 1996), both of which occur late in pregnancy and are thought to facilitate parturition. These effects are likely to be mediated via the glucocorticoid receptor (GR), access to which is dependent on local expression of the glucocorticoid-metabolizing enzymes $11 \beta$-hydroxysteroid dehydrogenase (11 $\beta$-HSD) types 1 and 2. Both of these enzymes are expressed in rat uterus
(Albiston et al. 1995, Burton et al. 1996, Roland \& Funder 1996, Ho et al. 1999, Waddell \& Burton 2000) in an oestrogen-dependent manner (Burton et al. 1998). The type 1 enzyme (11 $\beta-H S D-1)$ catalyses interconversion of corticosterone, the major active glucocorticoid in the rat, and the biologically inert 11-dehydrocorticosterone (11-DHC), although in vivo it appears to function as an 11-oxoreductase (Jamieson et al. 1995). In contrast, the type 2 enzyme (11 $\beta-H S D 2)$ exclusively catalyses inactivation of corticosterone to 11-DHC (11ßdehydrogenase activity) (Albiston et al. 1994). Thus, the two enzymes may act in concert to either enhance or limit glucocorticoid action in the myometrium.

Recent studies show that $11 \beta-\mathrm{HSD}-1$ is expressed in the non-pregnant rat uterus and this expression changes over the oestrous cycle (Burton et al. 1998), and increases after administration of gonadotrophins (Ho et al. 1999). 
Moreover, expression of $11 \beta-H S D-1$ increases dramatically in the uterine myometrium over the last week of pregnancy (Burton et al. 1996), a change that is dependent on the placenta (Waddell \& Burton 2000). The non-

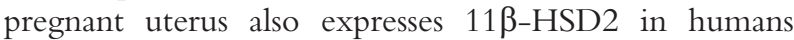
(Smith et al. 1997b) and rats (Burton et al. 1998, Ho et al. 1999), but it is not known whether this expression changes with the onset and progression of pregnancy. The continued presence of $11 \beta-\mathrm{HSD} 2$ in pregnant rat myometrium is predicted, however, by our observation that considerable $11 \beta$-dehydrogenase activity is measurable in fragments of myometrium throughout gestation (Burton et al. 1996), and mRNA encoding $11 \beta-H S D 2$ has been localized to rat myometrium near term (Roland \& Funder 1996). Potentially, changes in myometrial $11 \beta$ HSD2 could either negate or enhance the effects of the $11 \beta-H S D-1$ induction late in pregnancy, particularly since these enzymes appear to favour opposite catalytic activities in vivo. Therefore, the present study examined the patterns of $11 \beta-H S D 2$ mRNA, protein and bioactivity in the myometrium at various stages of rat pregnancy, with emphasis on the peripartum period. The relative inhibitory effects of progesterone and 20a-hydroxypregn-4-en-3one $(20 \alpha-\mathrm{OHP})$ on $11 \beta-\mathrm{HSD} 2$ bioactivity were also examined, since a dramatic reversal in the relative concentrations of these progestins occurs over the final days of rat pregnancy (Waddell et al. 1989). Although several progestins, including progesterone, can potently inhibit 11 $\beta-H S D$ activity (Lopez-Bernal et al. 1980, Baggia et al. 1990, Souness \& Morris 1996), it is not known whether 20 $\alpha$-OHP exerts a similar inhibitory effect on $11 \beta-H S D 2$.

\section{Materials and Methods}

\section{Animals and chemicals}

Nulliparous albino Wistar rats, 3-5 months old and weighing $269 \pm 34 \mathrm{~g}$ (means \pm S.D.) at mating were obtained from the Animal Resources Centre (Murdoch, WA, Australia). Rats were mated overnight and the morning on which spermatozoa were present in a vaginal smear was designated day 1 of pregnancy. All procedures involving animals were conducted only after approval by the Animal Ethics Committee of the University of Western Australia.

A Vectastain Elite ABC kit was purchased from Vector Laboratories (Burlingame, CA, USA). Corticosterone, biotinylated molecular weight standards and nitrocellulose membranes were obtained from Sigma Chemical Co. (St Louis, MO, USA). TLC plates precoated with silica gel $60 \quad \mathrm{~F}_{254}$ were obtained from Merck (Darmstadt, Germany), and $\left[1,2,6,7-{ }^{3} \mathrm{H}\right]$ corticosterone and $\left[\alpha_{-}{ }^{32} \mathrm{P}\right]$ deoxy-CTP were purchased from Amersham Australia (Sydney, Australia).

\section{Tissue preparation}

Tissues for Northern and Western blots were obtained from rats anaesthetized with halothane/nitrous oxide on the day of post-oestrus of the cycle, on days $5,10,16,22$ and 23 of pregnancy, and $24 \mathrm{~h}$ postpartum. Tissues were also obtained for $11 \beta$-HSD2 bioassays on each of these days except day 5 of pregnancy. Both uterine horns were removed immediately and myometrial tissue was isolated and collected as previously described (Burton et al. 1996), snap frozen on liquid nitrogen and stored at $-80{ }^{\circ} \mathrm{C}$ for subsequent Northern and Western blot analyses or placed into ice-cold phosphate-buffered saline (PBS; $\mathrm{pH} 7 \cdot 4$ ) containing $0.25 \mathrm{M}$ sucrose and homogenized for $11 \beta-$ HSD2 bioassays. Uterine tissue was also obtained for immunolocalization of $11 \beta-\mathrm{HSD} 2$ on days 16 and 22 of pregnancy and 1 day postpartum. These tissues were immersion fixed and then processed as previously described (Burton et al. 1996).

\section{Northern blot analysis}

Northern blot analysis ( $n=3$ per group) was performed as previously described (Burton et al. 1996). Briefly, total RNA was extracted using the single step guanidinium thiocynanate method (Chomczynski \& Sacchi 1987) and $30 \mu \mathrm{g}$ were fractionated by electrophoresis on $1 \%$ agarose$17 \%$ formaldehyde gels, transferred to nylon membranes (MagnaGraph from MSI, Westboro, MA, USA) by capillary blotting and fixed by UV crosslinking (UV Crosslinker RPN 2500; Amersham International plc, Aylesbury, Bucks, UK). Membranes were prehybridized $\left(0.2 \mathrm{M} \mathrm{NaH} \mathrm{PO}_{4}, 0.6 \mathrm{M} \mathrm{NaHPO}{ }_{4}, 5 \mathrm{mM}\right.$ EDTA, $200 \mu \mathrm{g}$ denatured herring testis DNA and 20\% SDS) for $4 \mathrm{~h}$ at $55^{\circ} \mathrm{C}$ and then hybridized overnight $\left(55^{\circ} \mathrm{C}\right)$ in identical buffer containing an $11 \beta-H S D 2$ cDNA probe (Albiston et al. 1994). The probe was labelled with $\left[\alpha-{ }^{32} \mathrm{P}\right]$ deoxy-CTP using a Random Primed DNA Labelling Kit (Boehringer Mannheim, Mannheim, Germany) and diluted to $2-3 \times 10^{6} \quad$ c.p.m. $/ \mathrm{ml}$. Membranes were washed to a final stringency of $0 \cdot 3 \times \mathrm{SSC}-0 \cdot 1 \%$ SDS at $55^{\circ} \mathrm{C}$ and exposed to Kodak XAR film (Eastman Kodak, Rochester, NY, USA) for 3 days. To confirm even loading of RNA, membranes were stripped and rehybridized under identical conditions with a $\left[\alpha-{ }^{32} \mathrm{P}\right]$ deoxy-CTP labelled $18 \mathrm{~S}$ probe. To quantify the $11 \beta-H S D 2$ and $18 \mathrm{~S}$ signals, hybridzed membranes were exposed to a Fuji Imaging Plate (Bas-IIIs; Fuji Photo Film Co., Tokyo, Japan), and the resultant images scanned using a Fuji Bioimager as previously described (Burton et al. 1996).

\section{Western blot analysis}

Western blot analysis ( $n=3$ per group) of $11 \beta-H S D 2$ was performed as previously described (Burton et al. 1998) 
using an antibody (RAH23, a kind gift of Dr Z Krozowski, Baker Medical Research Institute, Melbourne, Australia) raised against a portion of rat 11ß-HSD2 (Smith et al. 1997a). Briefly, myometrial tissue was homogenized in 4 vol. $10 \mathrm{~mm}$ sodium phosphate buffer (pH 7.0) containing 0.25 M sucrose, $1 \mu$ M EDTA, $1 \mu \mathrm{M}$ phenylmethylsulphonylfluoride and $100 \mu \mathrm{g} / \mathrm{ml}$ trypsin inhibitor. Microsomes were recovered by sequential centrifugation, subjected to Western blot analysis and $11 \beta-H S D 2$ signal visualized using a Vectastain Elite ABC kit. To quantify this signal, blots were incubated with a ${ }^{125}$ I-labelled anti-rabbit IgG secondary antibody (Amersham, Sydney, Australia), exposed on a Fuji Imaging Plate and the resultant images scanned and quantitated by densitometry using a Fuji Bioimager.

\section{Immunolocalization of $11 \beta$-HSD2}

Immunolocalization of $11 \beta-H S D 2$ was carried out as previously described for non-pregnant rat uterus (Burton et al. 1998). Briefly, after sectioning, paraffin was removed and non-specific staining blocked by incubation of tissue sections $(4 \mu \mathrm{m})$ with $3 \%$ hydrogen peroxide in methanol for $10 \mathrm{~min}$, followed by incubation with $2 \%$ bovine serum albumin-PBS-0.02\% Triton X-100 for $20 \mathrm{~min}$. Tissue sections were then exposed to immunopurified $11 \beta$ HSD2 antibody (see details in section on Western analyses) at a final concentration of $0.5 \mu \mathrm{g} / \mathrm{ml}$. Positive immunostaining was identified by the addition of an anti-rabbit IgG biotinylated secondary antibody followed by avidinbiotin-peroxidase complex (Vectastain Elite ABC kit) and diaminobenzidine. Sections were counterstained with Gill's haematoxylin.

\section{1ß-HSD2 bioassay}

Myometrial 11ß-HSD2 bioactivity was measured by the method previously described for rat corpus luteum (Waddell et al. 1996). Briefly, myometrial and kidney homogenates $(125-500 \mu \mathrm{g} / \mathrm{ml}$ supernatant protein; Bio-Rad protein assay kit; Bio-Rad, Hemel Hempstead, Herts, UK) were incubated with $\left[{ }^{3} \mathrm{H}\right]$ corticosterone $(15 \mathrm{nM}), 400 \mathrm{nM} \mathrm{NAD}^{+}$and varying concentrations of authentic corticosterone (range $0-515 \mathrm{nM}$ ). Preliminary studies established that linearity of conversion was maintained beyond the 10-min incubation at the protein concentration used. Duplicate incubations were carried out in a shaking water bath at $37^{\circ} \mathrm{C}$ for $10 \mathrm{~min}$ in a total volume of $0.25 \mathrm{ml}$. Incubations were stopped by the addition of $2.5 \mathrm{ml}$ ethyl acetate, into which steroids were extracted and isolated by thin-layer chromatography (chloroform:ethanol, 96:4). $\left[{ }^{3} \mathrm{H}\right]$ Corticosterone and $\left[{ }^{3} \mathrm{H}\right] 11-\mathrm{DHC}$ were quantified using liquid scintillation spectrometry. The reaction velocities (pmol 11-DHC formed/min per mg protein) for each incubation set were used to construct Lineweaver-Burk plots, from which the

\section{1ß-HSD-2 mRNA}

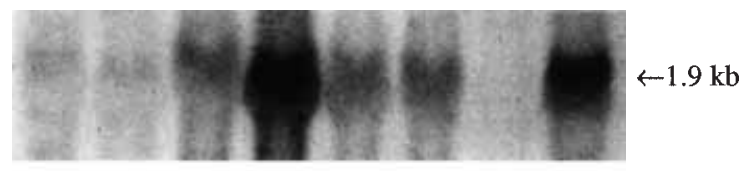

$18 S$

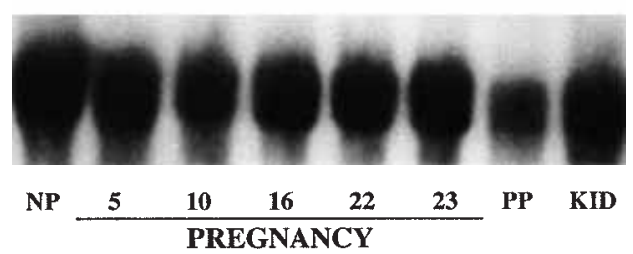

Figure 1 Northern blot analysis of total RNA from myometrium. The upper panel shows mRNA for $11 \beta-H S D 2$ and the lower panel $18 \mathrm{~S}$ before (NP), at different days throughout $(5,10,16,22,23)$ and $24 \mathrm{~h}$ after (PP) pregnancy. Maternal kidney (KID) was included as a positive control. Blots were probed with a

${ }^{32}$ P-labelled $11 \beta$-HSD2 cDNA, then stripped and reprobed with

${ }^{32}$ P-labelled $18 \mathrm{~S}$ cDNA to confirm RNA loading.

Michaelis-Menten constant $\left(K_{\mathrm{m}}\right)$ and maximum velocity $\left(\mathrm{V}_{\max }\right)$ values were derived (Palmer 1995). To assess inhibition of $11 \beta-\mathrm{HSD} 2$ bioactivity by progesterone and 20 $\alpha$-OHP, similar incubations were conducted with $\left[{ }^{3} \mathrm{H}\right]$ corticosterone $(15 \mathrm{nM})$ and authentic corticosterone $(100,200$ and $500 \mathrm{nM})$ in the presence of varying concentrations of these progestins $(0 \cdot 5,1 \cdot 0$ and $2 \cdot 0 \mu \mathrm{M})$, and the inhibitor constant $\left(K_{\mathrm{i}}\right)$ derived from a Dixon plot (Palmer 1995).

\section{Statistical analysis}

Changes in 11-HSD2 mRNA and immunoreactivity were assessed using two-way ANOVA and least significant difference (LSD) tests (Snedecor \& Cochran 1989), with each Northern or Western blot respectively containing a sample from each stage of pregnancy. Thus, within each two-way ANOVA, individual blots served as replicates $(n=3)$ and stages of pregnancy as treatments $(n=7)$. Changes in 11-HSD2 bioactivity with gestational age and the inhibitory effects of progesterone and $20 \alpha-\mathrm{OHP}$ at day 16 were assessed by one-way ANOVA and LSD tests (Snedecor \& Cochran 1989). Lineweaver-Burk and Dixon plots were determined by the method of least squares and the $K_{\mathrm{i}}$ derived from the Dixon plot by visual inspection.

\section{Results}

$11 \beta$-HSD2 $m R N A$ and protein expression

A single $1.9 \mathrm{~kb}$ transcript of $11 \beta-\mathrm{HSD} 2$ mRNA was evident from Northern blot analysis of myometrium at all 


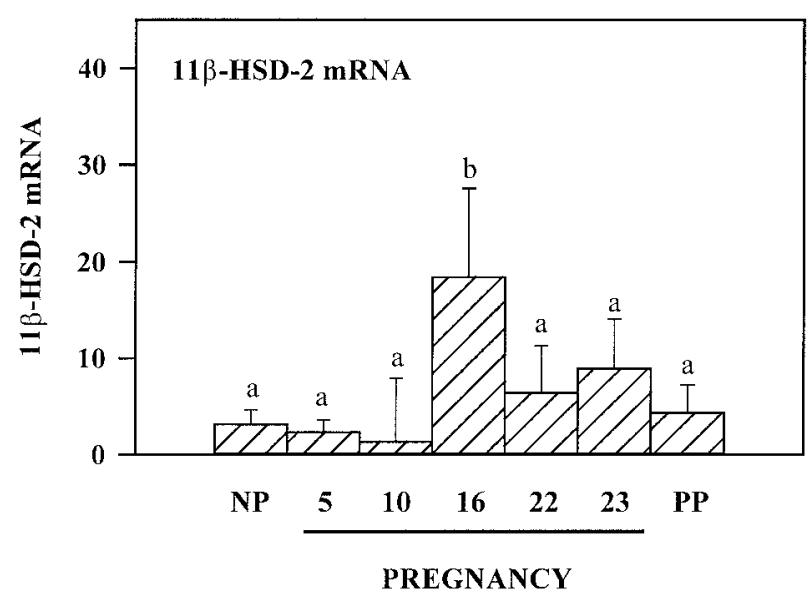

Figure 2 Quantitation of myometrial 11 -HSD2 mRNA expression (arbitrary units) measured by Northern blot analysis before (NP), at different days throughout $(5,10,16,22,23)$ and $24 \mathrm{~h}$ after (PP) pregnancy. Northern blots were exposed onto a phosphor imaging plate and the resultant images quantified with a Fuji Bioimager. Values are the means \pm S.E.M. ( $n=3$ per group), and those without common letter superscripts differ significantly $(P<0 \cdot 05$, two-way ANOVA and LSD tests).

stages examined, and corresponded with that in a kidney positive control (Fig. 1). Quantification of this mRNA signal showed that levels varied significantly over gestation $(P<0 \cdot 05$; two-way ANOVA), being higher at day 16 compared with all other stages $(P<0 \cdot 05$, LSD test; Fig. 2$)$. Consistent with this pattern of $11 \beta-H S D 2$ mRNA expression, Western blot analysis of myometrium demonstrated the presence of a $40 \mathrm{kDa} 11 \beta-\mathrm{HSD} 2$ protein (comparable to that in kidney positive control) at all stages examined (Fig. 3). Quantitative analysis showed that this $11 \beta$-HSD2 immunoreactive signal also varied significantly across pregnancy $(P<0 \cdot 05$, two-way ANOVA), with maximal levels evident on days 16 and $23(P<0 \cdot 05$, LSD test; Fig. 4). This immunoreactive signal was localized specifically to myometrial cells at all stages of pregnancy

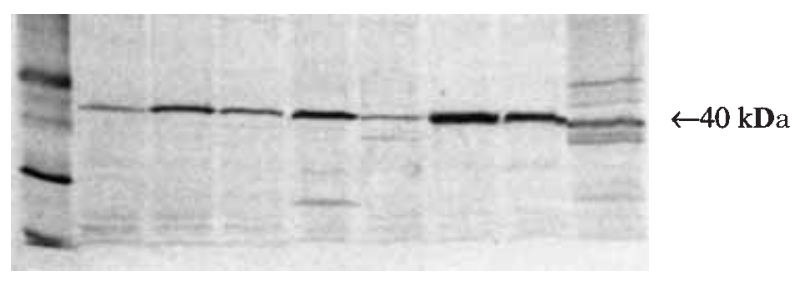

\section{$\begin{array}{llllllll}\text { STD NP } & 5 & 10 & 16 & 22 & 23 & \text { PP } & \text { KID }\end{array}$ PREGNANCY}

Figure 3 Western blot analysis of $11 \beta$-HSD2 protein in microsomal fractions of myometrium before (NP), at different days throughout $(5,10,16,22,23)$ and $24 \mathrm{~h}$ after (PP) pregnancy. Biotinylated molecular weight standards (STD) were used to estimate the molecular weight of immunostained proteins and maternal kidney (KID) was used as a positive control.

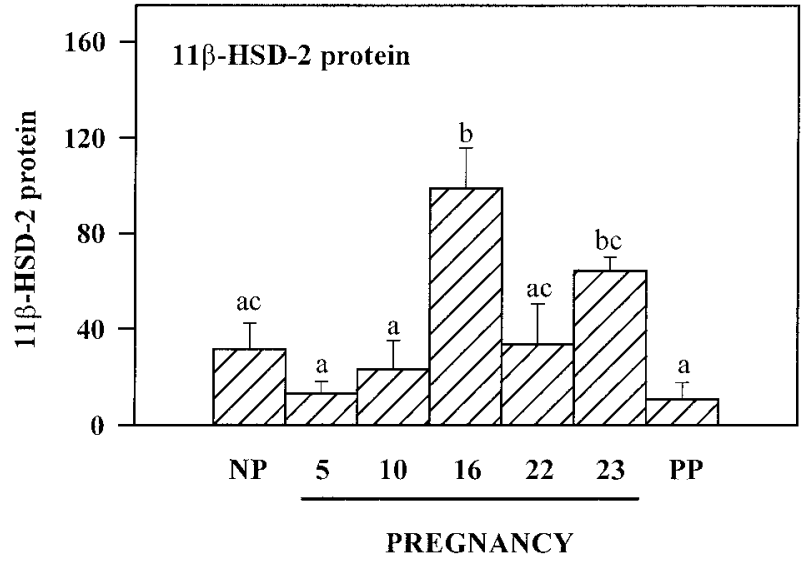

Figure 4 Quantitation of 11 $\beta$-HSD2 immunoreactivity (arbitrary units) measured by Western blot analysis of myometrium before (NP), at different days throughout $(5,10,16,22,23)$ and $24 \mathrm{~h}$ after (PP) pregnancy. After incubation with $11 \beta-H S D 2$ antiserum, blots were incubated with a ${ }^{125}$ I-labelled anti-rabbit IgG secondary antibody and exposed onto a phosphor imaging plate and the resultant images quantified with a Fuji Bioimager. Values are the means \pm S.E.M. ( $n=3$ per group), and those without common letter superscripts differ significantly $(P<0 \cdot 05$, two-way ANOVA and LSD tests).

examined and, consistent with the Western blot data, the intensity of immunostaining appeared considerably lower 1 day postpartum (Fig. 5a and c). Prominent staining for $11 \beta-H S D 2$ was also evident in stromal cells immediately adjacent to the reformed uterine luminal epithelium, but epithelial cells were clearly immunonegative (Fig. 5d).

\section{$11 \beta$-HSD2 bioactivity}

Bioactivity specific to $11 \beta-H S D 2$ was detectable in myometrium at all stages examined $\left(K_{\mathrm{m}}\right.$ in the range of 40-80 nM; Table 1), and $\mathrm{V}_{\max }$ (indicative of enzyme concentration) varied significantly with stage of gestation $(P<0 \cdot 01$, one-way ANOVA; Table 1$)$. Unlike the pattern for $11 \beta-H S D 2$ mRNA and protein, however, myometrial $11 \beta-H S D 2$ bioactivity was maximal before pregnancy and on the day of delivery (day 23), but there was no peak evident at day 16 . The apparent $K_{\mathrm{m}}$ also changed with the onset of pregnancy $(P<0 \cdot 05$, one-way ANOVA), increasing substantially from $47 \pm 11 \mathrm{nM}$ in non-pregnant myometrium to $75 \pm 7 \mathrm{nM}$ by day 10 , and remained elevated until returning to an intermediate level on the day of delivery $(60 \pm 8 \mathrm{nM})$.

\section{Inhibition of 11ß-HSD2 bioactivity by progesterone and 20a-OHP}

Because high concentrations of either progesterone or $20 \alpha-O H P$ are present for most of rat pregnancy, their possible inhibitory effects on myometrial $11 \beta-H S D 2$ bioactivity were examined. Progesterone clearly inhibited 

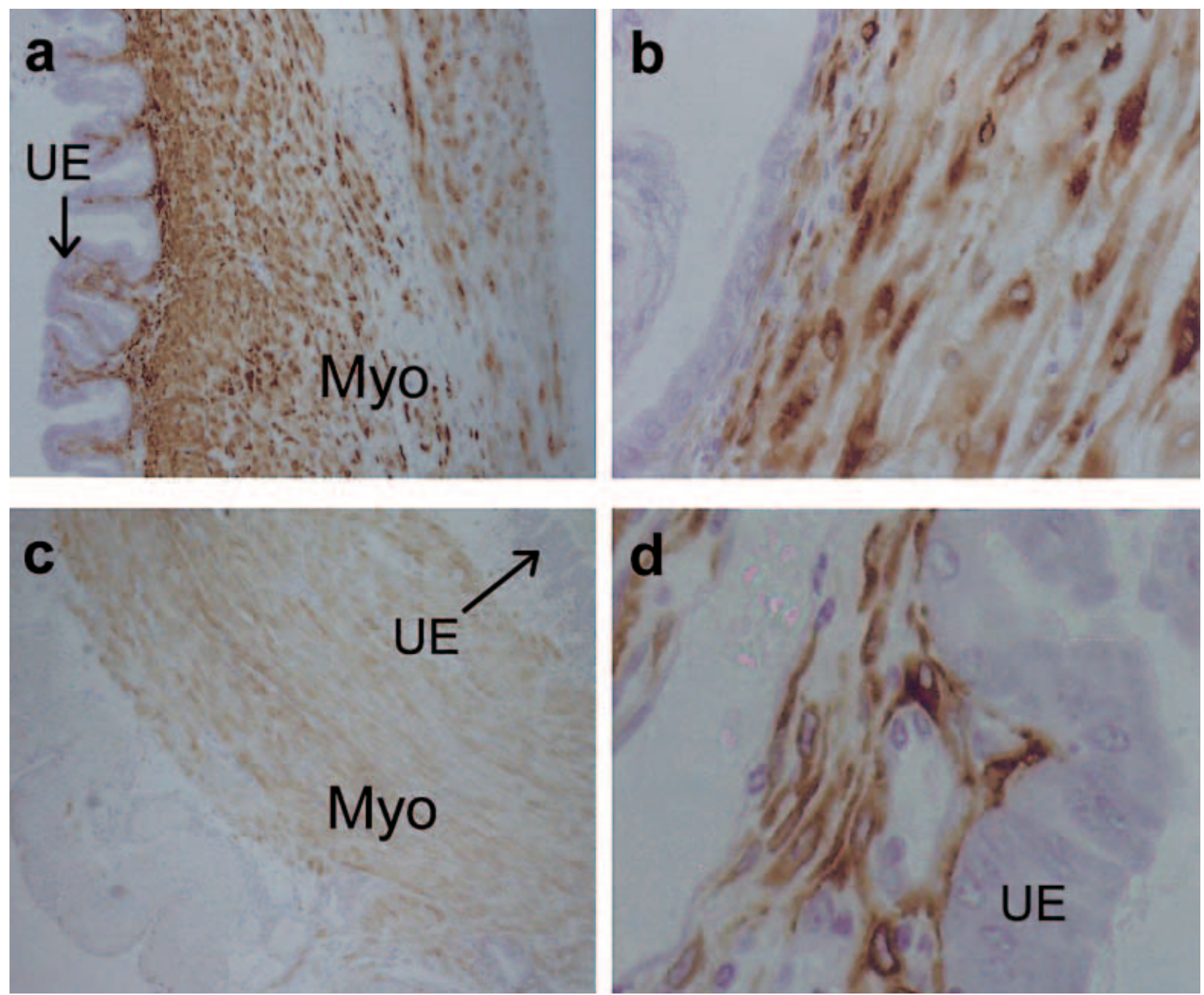

Figure 5 Immunolocalization of $11 \beta$-HSD2 in the rat uterus at days 16 and 22 of pregnancy and 1 day postpartum. (a) Day 16 of pregnancy; note positive immunoreactivity in the myometrium (Myo) and in stromal cells below uterine epithelium (UE). (b) Myometrial cells at day 22 (high-power view); note immunostaining for $11 \beta$-HSD2 in individual smooth muscle cells. (c) Day 1 postpartum; note reduced intensity of immunostaining in myometrium relative to day 16. (d) 11ß-HSD2 immunostaining of endometrial stromal cells on day 22 (high-power view); note absence of immunostaining in the overlying uterine epithelium.

$11 \beta-H S D 2$ bioactivity at all concentrations tested $(0 \cdot 5-$ $2 \cdot 0 \mu \mathrm{M}, P<0 \cdot 01$, Fig. 6), and the resultant Dixon plot is shown in Fig. 7. The derived $K_{\mathrm{i}}$ for progesterone was
$1.75 \mu \mathrm{M}$. In contrast, $20 \alpha-\mathrm{OHP}$ had no effect on $11 \beta-\mathrm{HSD} 2$ bioactivity over the same concentration range (Fig. 6).

Table $1 \mathrm{~V}_{\max }\left(\mathrm{pmol} / \mathrm{min}\right.$ per mg protein) and $K_{\mathrm{m}}(\mathrm{nM})$ for $11 \beta-\mathrm{HSD}-2$ bioactivity in myometrium obtained prior to (at post-oestrus (NP)), during (days 10, 16, 22 and 23) and after (24-h postpartum, PP) pregnancy. Values are the mean \pm S.E.M. ( $n=4$ per group)

\begin{tabular}{|c|c|c|c|c|c|c|c|}
\hline & NP & Day 10 & Day 16 & Day 22 & Day 23 & PP & $\boldsymbol{P}^{*}$ \\
\hline$V_{\max }$ & $3 \cdot 9 \pm 0 \cdot 5^{a}$ & $2 \cdot 0 \pm 0 \cdot 4^{b}$ & $\begin{array}{l}2 \cdot 4 \pm 0 \cdot 3^{\mathrm{bc}} \\
79+5^{\mathrm{b}}\end{array}$ & $\begin{array}{l}2 \cdot 4 \pm 0 \cdot 1^{\mathrm{bc}} \\
78+6^{\mathrm{b}}\end{array}$ & $2 \cdot 6 \pm 0 \cdot 1^{b c}$ & $3 \cdot 2 \pm 0 \cdot 1^{\text {ac }}$ & $<0.01$ \\
\hline
\end{tabular}

* $P$ value derived from one-way ANOVA; values without common superscripts differ significantly $(P<0 \cdot 05$, LSD test). 


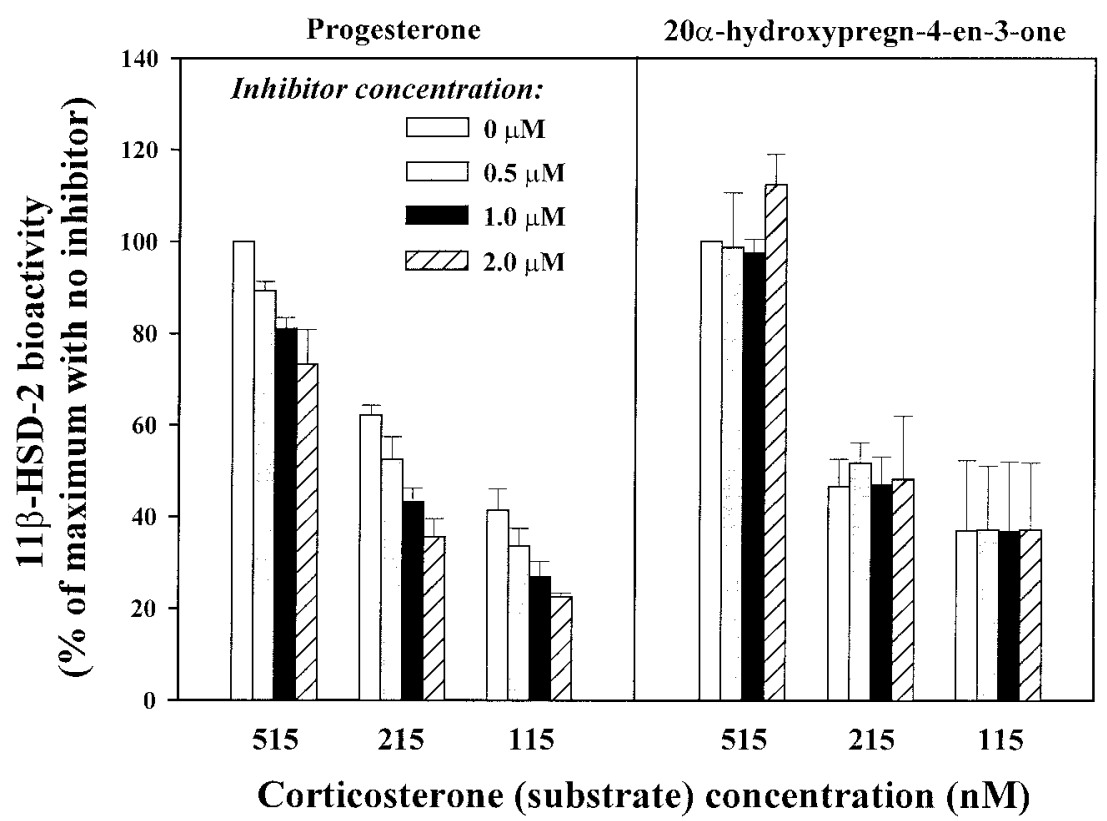

Figure 6 Inhibition of $11 \beta-$ HSD2 bioactivity in homogenates of day-16 myometrium by

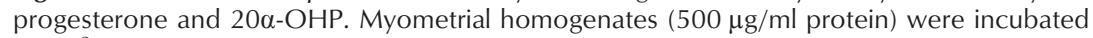
with $\left[{ }^{3} \mathrm{H}\right]$ corticosterone $(15 \mathrm{nM})$, authentic corticosterone $(100,200$ and $500 \mathrm{nM})$ and $\mathrm{NAD}^{+}(400 \mathrm{nM})$ in the presence of varying concentrations of either progesterone or $20 \alpha$-OHP $(0.5,1 \cdot 0$ and $2 \cdot 0 \mu \mathrm{M})$. Values shown are the reaction velocities expressed as a percentage of that measured in the presence of maximum substrate $(515 \mathrm{nM})$ and no inhibitor, and are the means \pm S.E.M. ( $n=3-4$ per group). $11 \beta$-HSD2 activity was inhibited at each concentration of progesterone $(P<0.01, P<0.001$ and $P<0.05$ for substrate concentrations of 115, 215 and $515 \mathrm{nM}$ respectively; two-way ANOVAs) but not $20 \alpha-\mathrm{OHP}$.

\section{Discussion}

Glucocorticoids exert a range of important effects on the uterine myometrium, particularly in the peripartum period (Challis et al. 2000, Whittle et al. 2001) when maternal and fetal plasma concentrations of corticosterone are maximal (Dupouy et al. 1987, Atkinson \& Waddell 1995). As in many other glucocorticoid target tissues, activation of the GR in myometrium is determined not only by blood concentrations of active glucocorticoid, but also by local expression of the $11 \beta-\mathrm{HSD}$ enzymes. We have previously demonstrated that $11 \beta-\mathrm{HSD}-1$ and -2 are both expressed in an oestrogen-dependent manner in the myometrium of the non-pregnant rat (Burton et al. 1998), and during pregnancy $11 \beta-H S D-1$ mRNA, protein and associated bioactivity increase dramatically near term (Burton et al. 1996, Waddell \& Burton 2000). The present study shows that $11 \beta-H S D 2 \mathrm{mRNA}$, protein and bioactivity are also present in rat myometrium before, during and after pregnancy, with mRNA and protein peaking at day 16. Moreover, $11 \beta-H S D 2$ was immunolocalized to myometrial smooth muscle cells, the same localization as that for 11 $\beta-H S D-1$ and the GR (Burton et al. 1996). Colocalization of the two $11 \beta-H S D$ enzymes within myometrial cells is similar to observations in the placenta of several species where both enzymes are expressed in trophoblast cells (for review see Burton \& Waddell 1999). The physiological consequences of myometrial colocalization are uncertain, however, since each enzyme is thought to favour catalysis of opposite reactions in vivo. Thus, $11 \beta-$ HSD2 exclusively catalyses $11 \beta$-dehydrogenase activity (glucocorticoid inactivation) (Albiston et al. 1994), whereas $11 \beta-H S D-1$ primarily exhibits 11-oxoreductase activity (Jamieson et al. 1995). Therefore, the net physiological effect of $11 \beta-H S D-1$ and -2 colocalization in myometrium is likely to depend on their relative expression levels and possibly local cofactor availability. We suggest that the more than 30-fold increase of myometrial $11 \beta-H S D-1$ expression and associated 11-oxoreductase activity near term (Burton et al. 1996) should over-ride the relatively stable $11 \beta$ dehydrogenase activity attributable to myometrial $11 \beta$ HSD2. This shift towards 11-oxoreductase dominance should increase local levels of active glucocorticoid within the myometrium and thereby enhance activation of the GR. The effects of glucocorticoids on several indices of myometrial function (Whittle et al. 2001) suggest that this increased GR activation would facilitate parturition. 


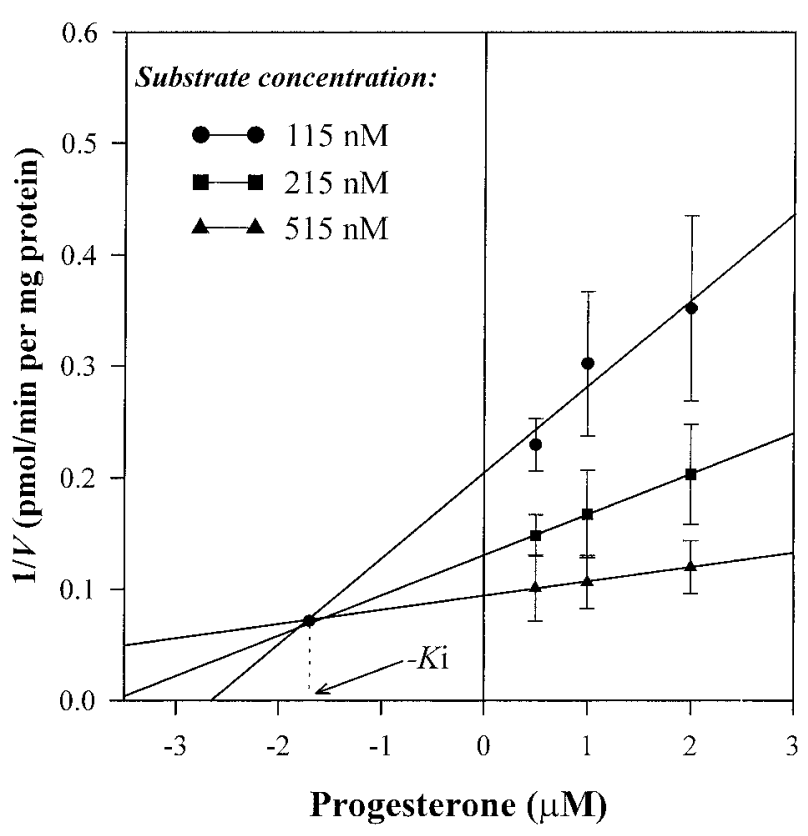

Figure 7 Dixon plot for progesterone inhibition of $11 \beta$-HSD2 bioactivity in homogenates of day-16 myometrium. Myometrial homogenates $(500 \mu \mathrm{g} / \mathrm{ml}$ protein) were incubated with $\left[{ }^{3} \mathrm{H}\right]$ corticosterone $(15 \mathrm{nM})$, authentic corticosterone $(100,200$ and $500 \mathrm{nM})$ and $\mathrm{NAD}^{+}(400 \mathrm{nM})$ in the presence of varying concentrations of progesterone $(0.5,1.0$ and $2.0 \mu \mathrm{M})$. Each line shows the reciprocal of the reaction velocities plotted against progesterone concentration, and the $K_{\mathrm{i}}$ was derived as the progesterone concentration at which the three resultant plots intercept $(1.75 \mu \mathrm{M})$. Values are the means \pm S.E.M. $(n=3-4$ per group).

The apparent $K_{\mathrm{m}}$ for myometrial $11 \beta$-HSD bioactivity was in the range of $40-80 \mathrm{nM}$, consistent with previously reported values for 11 $\beta$-HSD2-specific bioactivity (Albiston et al. 1994, Waddell et al. 1998). The fall in enzyme concentration (i.e. $\mathrm{V}_{\max }$ ) during pregnancy, however, was not paralleled by changes in either mRNA or protein expression, possibly reflecting a contribution of $11 \beta-H S D-1$ in the bioassay. Although the substrate concentrations $(15-215 \mathrm{nM})$ and cofactor $\left(\mathrm{NAD}^{+}\right)$used in the bioassay should limit such a contribution, it remains a possibility given the very high expression levels of 11ß-HSD-1 in myometrium near term (Burton et al. 1996).

Progesterone, but not $20 \alpha-\mathrm{OHP}$, clearly inhibited myometrial $11 \beta-\mathrm{HSD} 2$ in a competitive manner. The relatively high $K_{\mathrm{i}}$ of this inhibition $(1.75 \mu \mathrm{M})$, however, together with the relative concentrations of corticosterone and progesterone, suggest that this inhibition may be of minimal physiological importance. Plasma concentrations of corticosterone peak at around $1 \mu \mathrm{M}$ during late pregnancy (Atkinson \& Waddell 1995), whereas progesterone concentrations fall from a maximum of $0 \cdot 25 \mu \mathrm{M}$ at day 16 to only $0 \cdot 05 \mu \mathrm{M}$ at day 22 (Waddell et al. 1989). In contrast, progesterone inhibition of $11 \beta-\mathrm{HSD} 2$ in both human (Lopez-Bernal et al. 1980) and baboon (Baggia et al. 1990) placenta is likely to be physiologically relevant since the placenta of these species is a source of progesterone. Thus, local placental concentrations of progesterone are likely to be considerably higher than the $K_{\mathrm{i}}$ measured for inhibition of $11 \beta-H S D 2$ in this tissue (0.2 $\mu \mathrm{M}$; Baggia et al. 1990).

In conclusion, this study demonstrates that $11 \beta-\mathrm{HSD} 2$ is expressed in the rat myometrium throughout pregnancy, and is likely to interact with myometrial $11 \beta-\mathrm{HSD}-1$ to determine local concentrations of active glucocorticoid. Because of the facilitative role played by glucocorticoids in uterine contraction, the relative expression patterns of the two $11 \beta-H S D$ enzymes in myometrium near term (i.e. rising $11 \beta-\mathrm{HSD}-1 /$ stable $11 \beta-\mathrm{HSD} 2)$, are likely to make an important contribution to the complex hormonal control of parturition.

\section{Acknowledgements}

We thank Ms Susan Hisheh for assistance with Western blot analysis and Dr Zygmunt Krozowski (Baker Medical Research Institute, Melbourne, Australia) for providing the $11 \beta-H S D 2$ cDNA and antibody. This work was supported by the National Health and Medical Research Council of Australia (Project Grant 139104).

\section{References}

Albiston AL, Obeyesekere VR, Smith RE \& Krozowski ZS 1994 Cloning and tissue specific distribution of the human $11 \beta$-hydroxysteroid dehydrogenase type 2 enzyme. Molecular and Cellular Endocrinology 105 R11-R17.

Albiston AL, Smith RE \& Krozowski ZS 1995 Changes in the levels of $11 \beta$-hydroxysteroid dehydrogenase mRNA over the oestrous cycle in the rat. Journal of Steroid Biochemistry and Molecular Biology 52 45-48.

Atkinson HC \& Waddell BJ 1995 The hypothalamic-pituitary-adrenal axis in rat pregnancy and lactation: circadian variation and interrelationship of plasma adrenocorticotropin and corticosterone. Endocrinology 136 512-520.

Baggia S, Albrecht ED \& Pepe GJ 1990 Regulation of $11 \beta$ hydroxysteroid dehydrogenase activity in the baboon placenta by estrogen. Endocrinology 126 2742-2748.

Burton PJ \& Waddell BJ 1999 Dual function of $11 \beta$-hydroxysteroid dehydrogenase in placenta: modulating glucocorticoid passage and local steroid action. Biology of Reproduction 60 234-240.

Burton PJ, Dharmarajan AM, Hisheh S \& Waddell BJ 1996 Induction of myometrial $11 \beta$-hydroxysteroid dehydrogenase type 1 messenger ribonucleic acid and protein expression late in rat pregnancy. Endocrinology 135 5700-5706.

Burton PJ, Krozowski ZS \& Waddell BJ 1998 Immunolocalization of $11 \beta$-hydroxysteroid dehydrogenase types 1 and 2 in rat uterus: variation across the estrous cycle and regulation by estrogen and progesterone. Endocrinology 139 376-382.

Casey ML, MacDonald PC \& Mitchell MD 1985 Despite a massive increase in cortisol secretion in women during parturition, there is an equally massive increase in prostaglandin synthesis. A paradox? Journal of Clinical Investigation 75 1852-1857. 
Challis JRG, Matthews SG, Gibb W \& Lye SJ 2000 Endocrine and paracrine regulation of birth at term and preterm. Endocrine Reviews 21 514-550.

Chomczynski P \& Sacchi N 1987 Single-step method of RNA isolation by acid guanidium thiocyanate-phenol-chloroform extraction. Analytical Biochemistry 162 156-159.

Dupouy JP, Chatelain A, Boudouresque F, Conte-Devolx B \& Oliver C 1987 Effects of chronic maternal dexamethasone treatment on the hormones of the hypothalamic-pituitary-adrenal axis in the rat fetus. Biology of the Neonate 52 216-222.

Ho CK, Tetsuka M \& Hillier SG 1999 Regulation of $11 \beta$ hydroxysteroid dehydrogenase isoforms and glucocorticoid receptor gene expression in the rat uterus. Journal of Endocrinology 163 425-431.

Jamieson PM, Chapman KC, Edwards CRW \& Seckl JR 1995 $11 \beta$-Hydroxysteroid dehydrogenase is an exclusive $11 \beta$-reductase in primary cultures of rat hepatocytes: effect of physicochemical and hormonal manipulations. Endocrinology 136 4754-4761.

Lopez-Bernal A, Flint APF, Anderson ABM \& Turnbull AC 1980 $11 \beta$-Hydroxysteroid dehydrogenase activity (E.C.1.1.1.146) in human placenta and decidua. Journal of Steroid Biochemistry and Molecular Biology 13 1081-1087.

Palmer T 1995 Understanding Enzymes, edn 4. London: Prentice Hall.

Roland BL \& Funder JW 1996 Localization of $11 \beta$-hydroxysteroid dehydrogenase type 2 in rat tissues: in situ studies. Endocrinology 137 1123-1128.

Smith RE, Li KZX, Andrews RK \& Krozowski Z 1997a Immunohistochemical and molecular characterization of the rat $11 \beta$-hydroxysteroid dehydrogenase type II enzyme. Endocrinology $138540-547$.

Smith RE, Salamonsen LA, Komesaroff PA, Li KXZ, Myles KM, Lawrence M \& Krozowski Z $1997 b$ 11ß-Hydroxysteroid dehydrogenase type II in the human endometrium: localization and activity during the menstrual cycle. Journal of Clinical Endocrinology and Metabolism 82 4252-4257.
Snedecor GW \& Cochran WG 1989 Statistical Methods. Ames, Iowa: Iowa State University Press.

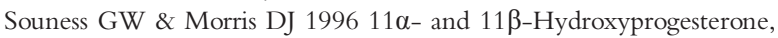
potent inhibitors of $11 \beta$-hydroxysteroid dehydrogenase, possess hypertensinogenic activity in the rat. Hypertension 27 421-425.

Waddell BJ \& Burton PJ 2000 Full induction of rat myometrial $11 \beta$-hydroxysteroid dehydrogenase type 1 in late pregnancy is dependent on intrauterine occupancy. Biology of Reproduction $\mathbf{6 2}$ 1005-1009.

Waddell BJ, Bruce NW \& Dharmarajan AM 1989 Changes in ovarian blood flow and secretion of progesterone and $20 \alpha$-hydroxypregn4-en-3-one on day 16 and the morning and afternoon of day 22 of pregnancy in the rat. Biology of Reproduction 41 990-996.

Waddell BJ, Benediktsson R \& Seckl JR 1996 11ß-Hydroxysteroid dehydrogenase type 2 in the rat corpus luteum: induction of mRNA expression and bioactivity coincident with luteal regression. Endocrinology 137 5386-5391.

Waddell BJ, Benediktsson R, Brown RW \& Seckl JR 1998 Tissue specific messenger ribonucleic acid expression of $11 \beta$ hydroxysteroid dehydrogenase types 1 and 2 and the glucocorticoid receptor within rat placenta suggests exquisite local control of glucocorticoid action. Endocrinology 139 1517-1523.

Whittle WL, Patel FA, Alfaidy N, Holloway AC, Fraser M, Gyomorey S, Lye SJ, Gibb W \& Challis JRG 2001 Glucocorticoid regulation of human and ovine parturition: the relationship between fetal hypothalamic-pituitary-adrenal axis activation and intrauterine prostaglandin production. Biology of Reproduction 64 1019-1034.

Wu WX, Derks JB \& Nathanielsz PW 1996 Effects of glucocorticoids on estrogen receptor messenger ribonucleic acid in the pregnant ovine myometrium in vivo and in vitro. Biology of Reproduction $\mathbf{5 4}$ 230-241.

Received 31 October 2001

Accepted 16 November 2001 